though, is the prompt creation of a long-promised evaluation agency to assess teaching and research performance and link them to university budgets. Also critical is money - just as throwing money at the problem won't solve the malaise on its own, reforms without additional funds won't be effective.

A law to reform universities was drafted in 2007 by the previous, centre-left government, which also proposed setting up an evaluation agency, known as ANVUR (National Agency for the Evaluation of the University and Research System), modelled on France's AERES agency. The current, centre-right government picked up and tweaked that draft. In doing so, it inserted the authority of its powerful finance ministry, which will directly manage some funds, and sign off annual budgets and budget proposals for each university. But the law also introduces some radical changes that could improve things. For example, it brings in mandatory peer review of all public research money, requiring that $30 \%$ of individuals who sit on peer-review committees are working abroad. This will help to avert high-profile debacles like the ministry of health's behind-closed-doors allocation in 2007 of a $€ 3$-million (US\$4-million) grant from its stem-cell research fund to scientists at a private foundation who claimed to be working more ethically than others - and the reversal of that decision following public outcry.

Changes in the system for recruiting staff may also help, but not necessarily. Traditionally, academic staff have been selected by national committees and then allocated to universities to fill relevant vacancies. Incomprehensible to many of those in other countries, where universities choose their own staff, the 'concorsi' system was intended to challenge a tendency to recruit locally, without necessarily

choosing the best. But behind-the-scenes dealing among concorsi committees ensured that universities mostly got the candidates they wanted anyway, for good or bad. Extensive tinkering in the past decade or so has not yet found a better balance between quality control at a national level and local university autonomy. In the new system, all candidates who pass a national qualification exam, judged by commit-

"Italians are familiar with fine-sounding reforms that fail to actually change things." tees similar to concorsi committees, will join a national list from which a university may at any time select a candidate. The danger here is that less academically suitable people may get on the list, because - as there is no link to a concrete academic position - committees don't bear responsibility for their choices.

Italians are familiar with fine-sounding reforms, such as the attempts to improve the concorsi system, that fail to actually change things. They enjoy quoting Giuseppe Tomasi di Lampedusa's The Leopard, a novel set around the time of Italy's unification in 1861, in which a protagonist observes contemporary politics, and wryly notes how the newly empowered try to 'change everything, so that everything remains the same'. But this law has a strong chance of changing things so that they do become different - and better. A crucial foundation for such success is that the government makes ANVUR happen soon. It was, after all, founded in law in February this year. Now, Italian scientists must see it built in bricks and mortar. The system needs more money, but that money must be linked to performance. Establishing ANVUR would show that Italy has placed its university system on the road to true reform.

\section{Calm in a crisis}

\section{Jane Lubchenco, Nature's Newsmaker of the Year, shows how scientists can help society.}

$\mathrm{F}$ or almost three months this year, a mini-volcano of oil and gas erupted into the Gulf of Mexico and disgorged nearly 5 million barrels of petroleum. Throughout the crisis, a poised scientist gave countless media interviews to explain to a scared and angry public how the US government was striving to contain the damage. Behind the scenes, with decisive leadership, she ran the National Oceanic and Atmospheric Administration (NOAA) - the agency that closed fisheries, tracked oil, protected habitats and assessed the damage to communities and the environment. For her role in the response to the crisis, Jane Lubchenco is Nature's Newsmaker of the Year (see page 1024).

Before becoming NOAA administrator in 2009, Lubchenco had a reputation as both a leading researcher and an environmental advocate. She made important advances in the basic science of coastal ecology and helped to raise awareness of the many threats to ocean ecosystems around the world. Lubchenco is now reorienting her US\$4.7-billion federal agency to strengthen the science and policies that protect US marine resources.

The United States could do with more scientists like Lubchenco, with the skills and the dedication to speak out on issues that matter. The need will be particularly acute next year, when the Republican Party takes over the US House of Representatives. Although Republicans have generally supported basic science, incoming House leaders have made it clear that they are hostile to certain areas of research. Some have pledged to hold hearings on climate science, which they argue is seriously flawed and has overstated the evidence for global warming. Adrian Smith (Republican, Nebraska) introduced the YouCut Citizen Review, which calls on the US public to search the National Science Foundation website list of peer-reviewed grants for those they consider wasteful. And Darrell Issa (Republican, California), the incoming head of the powerful Committee

on Oversight and Government Reform, last year led an effort to revoke funding from the National Institutes of Health for studies of substance abuse and HIV risk in other countries (see Nature 460, 667; 2009).

Scientific leaders in the United States must stand up against such attacks. As a first step, they should try to meet with incoming House members from both parties to voice their concerns and explain the rationale behind research in controversial areas. Recognizing that all politics is local, scientists will need to make clear why climate change or HIV research matters for the communities represented by members of Congress. They should take along science-savvy business leaders and locally elected officials to help make their case.

Beyond the scientific leadership, there is a broader need for more individual scientists to communicate with the public. Currently, that kind of activity is not particularly valued - and is even disdained - in some fields of research. And spending time meeting with elected leaders or local journalists does not help a young scientist to get tenure.

Most scientists receive no training in public communication, and will need to hone their skills. Some can learn from experienced mentors; others can benefit from programmes developed by scientific societies and other groups (see page 1032). Members of academic and government agencies can consult with public-affairs representatives, who can show them the best ways to communicate the results and implications of research. Another avenue is the Congressional Science Fellowship programme, through which scientific societies can sponsor scientists to work in congressional offices for a year, providing advice to elected officials. The societies involved should expand their programmes, and groups that do not currently sponsor fellows should consider it.

As with any endeavour, it takes time to develop the communication skills that Lubchenco and other senior scientists have acquired. Even Lubchenco foundered at times during the oil spill. She made some mistakes and was criticized for the way that her agency initially downplayed the evidence for oil spreading below the surface. Despite such

$\checkmark$ NATURE.COM To comment online, click on Editorials at: go.nature.com/xhunqv slips, Lubchenco has steered her agency through the crisis with a steady hand. She is an outstanding example of how much one scientist can do to improve both society and natural ecosystems. Others would do well to follow her lead. 